\title{
Benign Ureter Neoplasm
}

National Cancer Institute

\section{Source}

National Cancer Institute. Benign Ureter Neoplasm. NCI Thesaurus. Code C3617.

Abnormal growth of the cells of the ureter (upper urinary tract) without malignant

characteristics. 